\section{Microbial Profile and Endotoxin Levels in Primary Periodontal Lesions with Secondary Endodontic Involvement}

Emanuel da Silva Rovai ${ }^{1}$, Felipe de Souza Matos $^{2}{ }^{D}$, Warley David Kerbauy ${ }^{3}$, Flávia Goulart da Rosa Cardoso ${ }^{2} \mathbb{B}$, Frederico Canato Martinho ${ }^{\mathbb{D}}$, Luciane Dias de Oliveira ${ }^{5}$, Marcia Carneiro Valera ${ }^{2} \mathbb{D}$, Cláudio Antonio Talge Carvalho ${ }^{2}$

\begin{abstract}
This study was carried out to investigate the microbial profile and endotoxin levels of endodontic-periodontal lesions of periodontal origin. Periodontal and endodontic samples were taken from periodontal pockets and necrotic root canals of 10 teeth with endodontic-periodontal lesions. Evidencing of 40 different bacterial species were determined in each endodontic and periodontal sample using the checkerboard DNA-DNA hybridization method and Kinetic chromogenic LAL assay was used for quantification of endotoxins. Fisher's exact test correlated the bacterial species with the endodontic or periodontal microbiota. The endotoxin levels $(\mathrm{EU} / \mathrm{mL})$ found in samples of the root canal and periodontal pocket were compared by the Wilcoxon test $(p<0.05)$. Bacteria and LPS units were found in $100 \%$ of the endodontic and periodontal samples. The species $E$. faecium, P. acnes, G. morbillorum, C. sputigena and L. buccalis were strongly correlated with the endodontic microbiota and $P$. nigrescens with the periodontal microbiota. $P$. intermedia, $P$. endodontalis and $V$. parvula were more prevalent in both endodontic and periodontal microbiots. The endotoxin levels in the periodontal pocket (89600 EU/ $\mathrm{mL}$ ) were significantly higher than in the root canal $(2310 \mathrm{EU} / \mathrm{mL})$. It was concluded that the microbiota present in the periodontal and endodontic tissues is similar, with a higher prevalence of species of the orange complex and a higher level of endotoxin in the periodontal pockets.
\end{abstract}

'School of Dentistry, Division of Periodontics, USP - Universidade de São Paulo, São Paulo, SP, Brazil ${ }^{2}$ Department of Restorative Dentistry, UNESP - Universidade Estadual Paulista, São José dos Campos, SP, Brazil ${ }^{3}$ Department of Surgery, Periodontics and Radiology, UNESP - Universidade Estadual Paulista, São José dos Campos, SP, Brazil ${ }^{4}$ University of Maryland School of Dentistry, Baltimore, Maryland, USA ${ }^{5}$ Department of Biosciences and Oral Diagnosis, UNESP Universidade Estadual Paulista, São José dos Campos, SP, Brazil

Correspondence: Cláudio Antonio Talge Carvalho, Avenida Eng Francisco José Longo, 777, 12245000 São José dos Campos, SP, Brasil. Tel: +55-12-39479050. e-mail: claudiotalge@ict.unesp.br

Key Words: DNA probes, endodontics, lipopolysaccharides, microorganisms, periodontal disease.

\section{Introduction}

The periodontal and endodontic tissues have embryonic, anatomical and functional interrelationships. As the tooth and root development, communication pathways are created between the periodontium and pulp, such as dentinal tubules, lateral and accessory canals, and the apical foramen. Through these communications, it is believed that microorganisms and toxins may pervade structures serving as a source for infection in a two-way relationship, resulting in pathological entities known as endodontic-periodontal lesions $(1,2)$.

Endodontic-periodontal lesions are characterized by the association of endodontic and periodontal disease in the same tooth. Such infections are typically multispecies and interactions among different microorganisms may contribute to the development of endodontic and periodontal flora (3). Studies that investigated teeth with periodontal and endodontic infection demonstrated that the microorganisms present in the root canals with advanced periodontal disease were similar to those found in the adjacent periodontal pockets $(2,4-8)$. Furthermore, Didilescu et al. (9) investigated the association of six bacterial species in endodontic-periodontal lesions and found that the species Fusobacterium nucleatum, Capnocytophaga sputigena and Parviromona micra were more prevalent, suggesting that these species may play a role in the pathogenesis of these lesions.

Lipopolysaccharide (LPS), also known as endotoxin, is the major macromolecule found in the outer cell membrane of Gram-negative bacteria being released after its division or death. It is an important virulence factor which plays a role in endodontic and periodontal infections and its presence has been correlated with clinical symptomatology and bone resorption in pulpal and periapical lesions $(10,11)$. LPS is considered one of the most potent inflammatory cascade initiators because it can activate monocytes and macrophages to produce proinflammatory cytokines such as tumor necrosis factor alpha (TNF-a), interleukins (IL) -1 , IL-6, IL -8, and IL-12 (12).

Until now, there are few studies regarding bacterial community of endodontic-periodontal lesions in the literature $(2,4-7,9)$ and, consequently, treatment protocols of these lesions are not well established in clinical practice. The qualitative and quantitative correlation of pathogens and endotoxins in the infection processes of endodonticperiodontal lesions may offer a better understanding of the 
disease and it is essential for the development of improved strategies for diagnosis and therapeutic intervention. Thus, the aim of the present study was to investigate the microbial profile by 40 different species and endotoxin levels of endodontic-periodontal lesions of periodontal origin.

\section{Material and Methods}

\section{Patient Selection}

Ten patients were selected among those seeking dental treatment at São José dos Campos Dental School. A detailed dental history was obtained from each patient. The study included subjects which presented teeth with pulp necrosis associated with periapical lesion, gingival bleeding and $\geq 6 \mathrm{~mm}$ periodontal pocket in more than one site. Pulp status was assessed through thermal vitality tests and cavity test. The periapical status was determined through the observation of clinical and radiographic signs, and symptoms such as tenderness to percussion and pain on palpation. Exclusion criteria were teeth with the pulp chamber exposed to the oral cavity, previous endodontic treatment, caries communicating to the pulp chamber, presence of cracks or fissures, calcifications and external resorption. The presence of cracks or fissures was assessed through transillumination, wedging and staining tests, followed by radiographic examination. Thus, the lesions were endodontic-periodontal lesions whose infection was probably of periodontal origin (13). In addition, were excluded patients who presented systemic diseases, those who had undergone periodontal treatment during the last 6 months prior to the study, smoking and antibiotic therapy during the last 6 months prior to the study. All subjects who agreed to participate in the study were informed about the nature and potential risks and signed a free informed consent form. Furthermore, the study was approved by the local Institute Review Board (CAAE: 30936714.8.0000.0077).

\section{Sample Collection}

All materials used in this study were treated with Co-gamma radiation (20 kGy for $6 \mathrm{~h}$ ) for sterilization and elimination of preexisting endotoxins (EMBRARAD; Empresa Brasileira de Radiação, Cotia, SP, Brazil). Initially, the supragingival plaque was removed by rubbing a sterile gauze moistened in saline solution on all faces of the tooth crown and air jets were applied in order to keep the tooth surface dry. The periodontal sites to be sampled were isolated with cotton rolls in order to avoid contamination by saliva.

Periodontal samples were first collected as follows: four pyrogen-free paper points \#30 (Dentsply, Petrópolis, RJ, Brazil) were inserted into the deepest periodontal pocket of the teeth, one at a time, where they remained for $1 \mathrm{~min}$.
The first paper point was transferred to an eppendorf tube and stored at $-20{ }^{\circ} \mathrm{C}$ until the limulus amebocyte lysate $(\mathrm{LAL})$ assay. The last three paper points were immediately transferred to one eppendorf tube containing $1 \mathrm{~mL}$ TrisEDTA buffer ( $10 \mathrm{mmol} / \mathrm{L}$ Tris-HCl, $1 \mathrm{mmol} / \mathrm{L}$ EDTA, $\mathrm{pH}=7.6)$. Then, $1 \mathrm{~mL}$ of $0.5 \mathrm{~mol} / \mathrm{L} \mathrm{NaOH}$ was added to each tube, and samples were frozen at $-20^{\circ} \mathrm{C}$ until they were processed for checkerboard DNA-DNA analyses.

Subsequently, endodontic samples were collected under absolute isolation with a rubber dam. The operative field (outer surface of crown, clamp, rubber dam and frame) was disinfected in three steps: first with $30 \%$ hydrogen peroxide, second with $5.25 \%$ sodium hypochlorite $(\mathrm{NaOCl})$ and third with $5 \%$ sodium thiosulfate. The access to the pulp chamber was made without the use of water spray but under manual irrigation with sterile/apyrogenic saline solution and by using sterile/apyrogenic high-speed diamond bur. All procedures were performed aseptically. Four paper points \# 15 (Dentsply, Petrópolis, RJ, Brazil) were consecutively introduced into the full length of the canal, which was determined radiographically. The storage method followed the same as periodontal samples.

\section{Microbiological Assay: Checkerboard DNA-DNA}

Counts of 40 different bacterial species (Table 1) were determined in each endodontic and periodontal sample, using the checkerboard DNA-DNA hybridization technique. DNA extraction was performed with the Qlaamp DNA kit (OIAGEN, Chatsworth, CA, USA) according to the manufacturer's instructions. Briefly, each sample suspension containing free DNA was deposited in the slits of a Minislot $30^{\oplus}$ (Immunetics, Cambridge, MA, USA) containing a positively charged nylon membrane $(15 \mathrm{x}$ $15 \mathrm{~cm}$ ) (Amersham Biosciences, Chicago, IL, USA), where the DNA was fixed by oven heating at $120^{\circ} \mathrm{C}$ for $20 \mathrm{~min}$. The last two channels of the Minislot $30^{\circledast}$ were reserved for the placement of the controls, containing a mixture of species of microorganisms that were investigated by DNA probes at concentrations $10^{5}$ and $10^{6}$ bacterial cells. DNA probes specific for the 40 species were made using Random Primer Digoxigenin Labeling kit (Boehringer Mannheim, Indianapolis, IN, USA), as described by Feinberg and Volgelstein (14). Prior to their use, the probes were tested with a control mixture containing the investigated species, at a concentration of $10^{4}$ bacterial cells. Their concentrations were adjusted such that the signal intensity of all probes became similar.

After fixation of DNA in the membrane, the DNA probes were hybridized perpendicular to the lines containing the bacterial DNA using a Miniblotter $45^{\oplus}$ device (Immunetics, Cambridge, MA, USA). Bound probes were detected using anti-digoxigenin antibody (Roche Diagnostics $\mathrm{GmbH}$, 
Mannheim, Germany) conjugated to alkaline phosphatase (Boehringer, Mannheim, Germany), at a dilution of $1 / 25000$, and by chemiluminescence using CDP-Star Detection Reagent ${ }^{\oplus}$ (Amershan Biosciences UK Limited, Buckinghamshire, UK). The membranes were placed in cassette under a Kodak ${ }^{\oplus}$ X-OMAT radiographic film (Kodak Brasileira Com. e Ind. Ltda, São José dos Campos, SP, Brazil) for approximately $40 \mathrm{~min}$, and the films were revealed shortly thereafter. Each signal produced by a given probe in the root canals sample was compared with the signal produced by the same probe in the two controls containing $10^{5}$ and $10^{6}$ bacterial cells.

\section{Quantification of Endotoxins: Kinetic Chromogenic LAL ASSAY}

The method used for measuring the endotoxin levels has been previously published (11). First, $1 \mathrm{~mL}$ of apyrogenic water was added to each tube containing the paper point and the endotoxin extraction was performed by mechanical shaking in vortex for $60 \mathrm{~s}$. Subsequently, endotoxin suspensions were serially diluted to 10-1. Kinetic chromogenic limulus amebocyte lysate assay (Lonza, Walkersville, MD, USA) was used for quantification of $\vec{\sigma}$ endotoxins. As a parameter for calculating the amount of endotoxins in periodontal and endodontic samples, a standard curve was plotted by using endotoxins supplied in the kit with a known concentration $(50 \mathrm{EU} / \mathrm{mL})$ and their dilutions $(0.005,0.05,0.5$, and $5 \mathrm{EU} / \mathrm{mL})$ according to the manufacturer's instructions. Endotoxin from Escherichia coli was used as standard. A positive control (periodontal and endodontic samples contaminated with a known amount of endotoxin - $10 \mathrm{EU} / \mathrm{mL}$ ) was included for each sample to determine the presence or absence of interfering agents. A 96-well apyrogenic plate (Easypath, São Paulo, SP, Brazil) was used in a heating block at $37^{\circ} \mathrm{C}$ and maintained at this temperature throughout the assay. For the test, $100 \mu \mathrm{L}$ of apyrogenic water (blank), 5 standard endotoxin solutions $(0.005-50 \mathrm{EU} / \mathrm{mL})$, periodontal and endodontic samples, and positive controls (each periodontal and endodontic sample contaminated with a known concentration of endotoxin - $10 \mathrm{EU} / \mathrm{mL}$ ) were added to the 96-well apyrogenic plate. The tests were carried out in quadruplicate. The plate was incubated at $37 \pm 1^{\circ} \mathrm{C}$ for $10 \mathrm{~min}$ in a KineticOCL reader, which was coupled to a computer with the WinKOCL software (Lonza). Then, 100 $\mu \mathrm{L}$ of the chromogenic reagent was added to each well. As soon as the kinetic test started, absorbance at $405 \mathrm{~nm}$ was read in each microplate well and automatically calculated the $\log / \log$ linear correlation between reaction time of each standard solution and corresponding endotoxin concentration.

\section{Statistical Analysis}

Investigation of 40 bacterial species in each endodontic and periodontal sample was expressed in mean prevalence and levels of each species in each sample. Prevalence was determined based on the proportions of endodontic and periodontal sample colonized by each bacterial species at counts $<10^{5}, 10^{5}, 10^{5}-10^{6}$ and $10^{6}$. Fisher's exact test was used to correlate the bacterial species with the endodontic or periodontal microbiota. The endotoxin levels $(E U / \mathrm{mL})$ found in the root canal and periodontal pocket samples were compared by the Wilcoxon test. The level of significance was set at $5 \%$.

Table 1. DNA probes of bacterial strains

\begin{tabular}{|c|c|}
\hline Complex & Species (strain) \\
\hline Red & $\begin{array}{l}\text { Porphyromonas gingivalis (33277a), Tannerella forsythia (43037a), } \\
\text { Treponema denticola }\left(\mathrm{B} 1^{\mathrm{b}}\right)\end{array}$ \\
\hline Purple & Actinomyces odontolyticus (17929a), Veillonella parvula (10790a) \\
\hline Green & $\begin{array}{l}\text { Agregatibacter actinomycetemcomitans }\left({ }^{\mathrm{a}}+\mathrm{b}\right)\left(43718^{\mathrm{a}} \text { and } 29523^{\mathrm{a}}\right) \text {, } \\
\text { Capnocytophaga gingivalis }\left(33624^{\mathrm{a}}\right) \text {, Capnocytophaga ochracea }\left(33596^{\mathrm{a}}\right) \text {, } \\
\text { Capnocytophaga sputigena }\left(33612^{\mathrm{a}}\right) \text {, Eikenella corrodens }\left(23837^{\mathrm{a}}\right)\end{array}$ \\
\hline Orange & 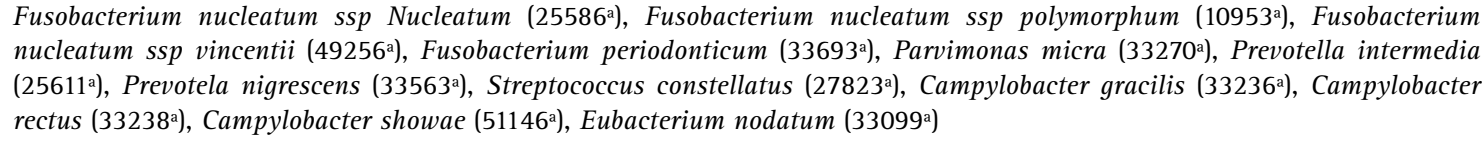 \\
\hline Yellow & $\begin{array}{l}\text { Streptococcus gordonii }\left(10558^{a}\right) \text {, Streptococcus intermedius (27335a), } \\
\text { Streptococcus mitis }\left(49456^{a}\right) \text {, Streptococcus sanguinis }\left(10556^{\mathrm{a}}\right)\end{array}$ \\
\hline Other & $\begin{array}{l}\text { Actinomyces israelli }\left(12102^{\mathrm{a}}\right) \text {, Actinomyces oris }\left(43146^{\mathrm{a}}\right) \text {, Enterococcus faecalis }\left(29212^{\mathrm{a}}\right) \text {, Enterococcus faecium }\left(6569^{\mathrm{a}}\right) \text {, Eubacterium } \\
\text { saburreum }\left(33271^{\mathrm{a}}\right), \text { Gemella morbillorum }\left(27824^{\mathrm{a}}\right) \text {, Leptotrichia buccalis }\left(14201^{\mathrm{a}}\right) \text {, Neisseria mucosa }\left(19696^{\mathrm{a}}\right), \text { Porphyromonas } \\
\text { endodontalis }\left(35406^{\mathrm{a}}\right) \text {, Prevotella melaninogenica }\left(25845^{\mathrm{a}}\right) \text {, Propionybacterium acnes (I+II) }\left(11827^{\mathrm{a}} \text { and } 11282^{\mathrm{a}}\right) \text {, Selemonas noxia } \\
\left.\left(43541^{\mathrm{a}}\right), \text { Strepctococcus anginosus }\left(33397^{\mathrm{a}}\right) \text {, Treponema socranskii (S1 }{ }^{\mathrm{b}}\right)\end{array}$ \\
\hline
\end{tabular}

${ }^{\mathrm{a}}$ : American Type Culture Collection. ${ }^{\mathrm{b}}$ : Forsyth Institute, Boston, MA. 


\section{Results}

Prevalence and levels of each bacterial species in endodontic and periodontal samples are presented in Figure 1 and Figure 2, respectively. Microorganisms were found in $100 \%$ of the samples by checkerboard DNA-DNA hybridization. Among 40 bacterial species evaluated, six species, including S. noxia, S. gordonii, F. nucleatum ssp polymorphum, $S$. anginosus, E. saburreum and $A$. actinomycetemcomitans, were not detected in any endodontic sample. The most prevalent species at this site were $P$. endodontalis $(80 \%)$, L. buccalis $(80 \%)$, C. sputigena $(70 \%)$, E. faecium $(70 \%)$, A. oris $(70 \%)$, V. parvula $(70 \%)$, P. micra (70\%), P. intermedia (60\%), G. morbillorum (60\%) and E. nodatum (60\%) (Fig 1).

Regarding the periodontal samples, 14 microorganisms were not found: C. gracilis, C. sputigena, $G$. morbillorum, E. corrodens, P. acnes, S. noxia, C.

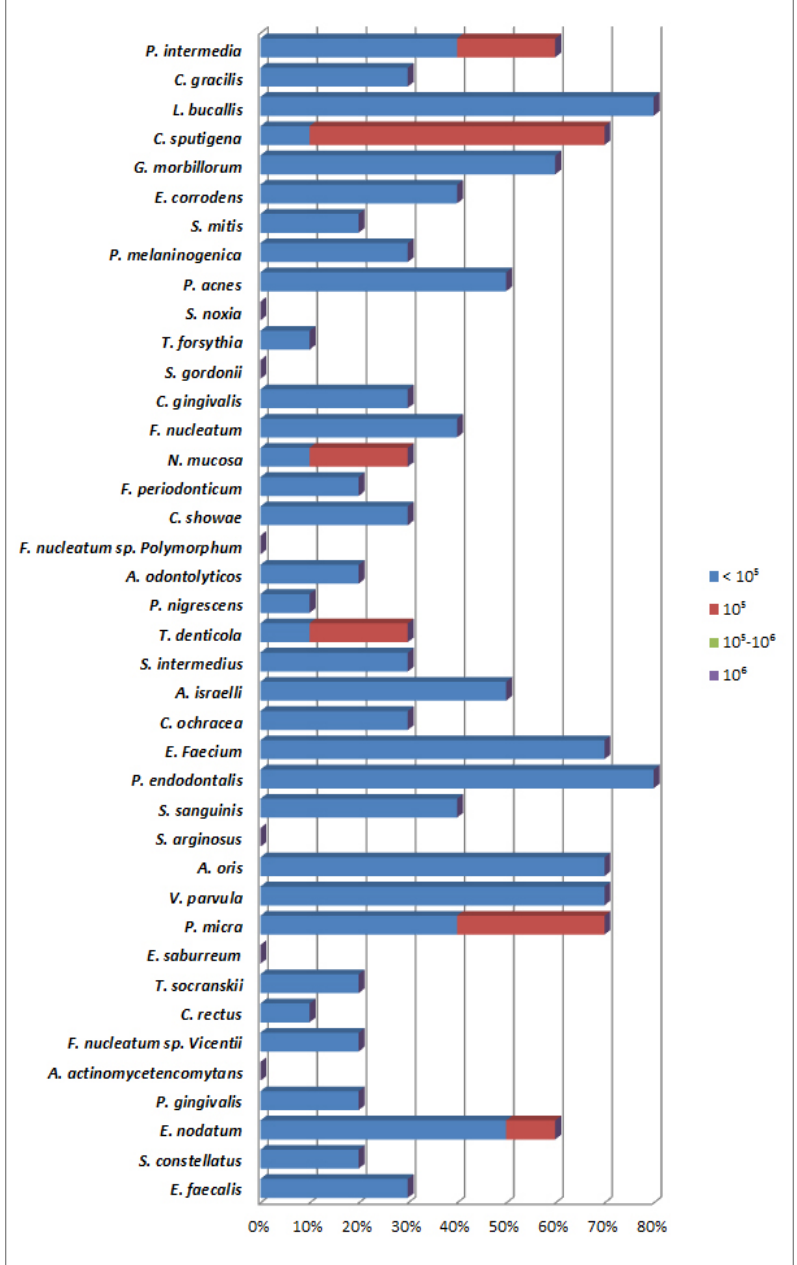

Figure 1 . The mean prevalence ( $\%$ endodontic sample colonized) and levels $\left(<10^{5}, 10^{5}, 10^{5}-10^{6}\right.$ and $\left.10^{6}\right)$ of each bacterial species in samples of the root canal of endodontic-periodontal lesions. The total length of each bar indicates percentage of positive samples. Different colors inside each bar indicate percentage of samples containing different levels of bacterial DNA. gingivalis, N. mucosa, A. odontolyticus, E. faecium, C. ochracea, S. sanguinis, E. saburreum and $A$. actinomycetemcomitans. The most prevalent bacterial species in these samples were: $P$. nigrescens $(70 \%), P$. intermedia $(50 \%), V$. parvula $(50 \%)$, F. nucleatum ssp vincentii (50\%), P. gingivalis (40\%), P. endodontalis (40\%), F. nucleatum (40\%) and E. nodatum (40\%) (Fig. 2).

According to Fisher's exact test, the species $E$. faecium ( $p=0.0031)$, P. acnes $(p=0.0325)$, G. morbillorum $(p=0.0108)$, C. sputigena $(\mathrm{p}=0.0031)$ and $L$. buccalis $(\mathrm{p}=0.0055)$ were strongly correlated with the endodontic microbiota. The species $P$. nigrescens was strongly correlated with the periodontal microbiota $(p=0.0198)$. Although $P$. intermedia $(\mathrm{p}=0.75)$, $P$. endodontalis $(\mathrm{p}=0.34)$ and $V$. parvula $(\mathrm{p}=0.34)$ presented a weak correlation with both endodontic and periodontal microbiots, these bacteria were the most prevalent in both sites.

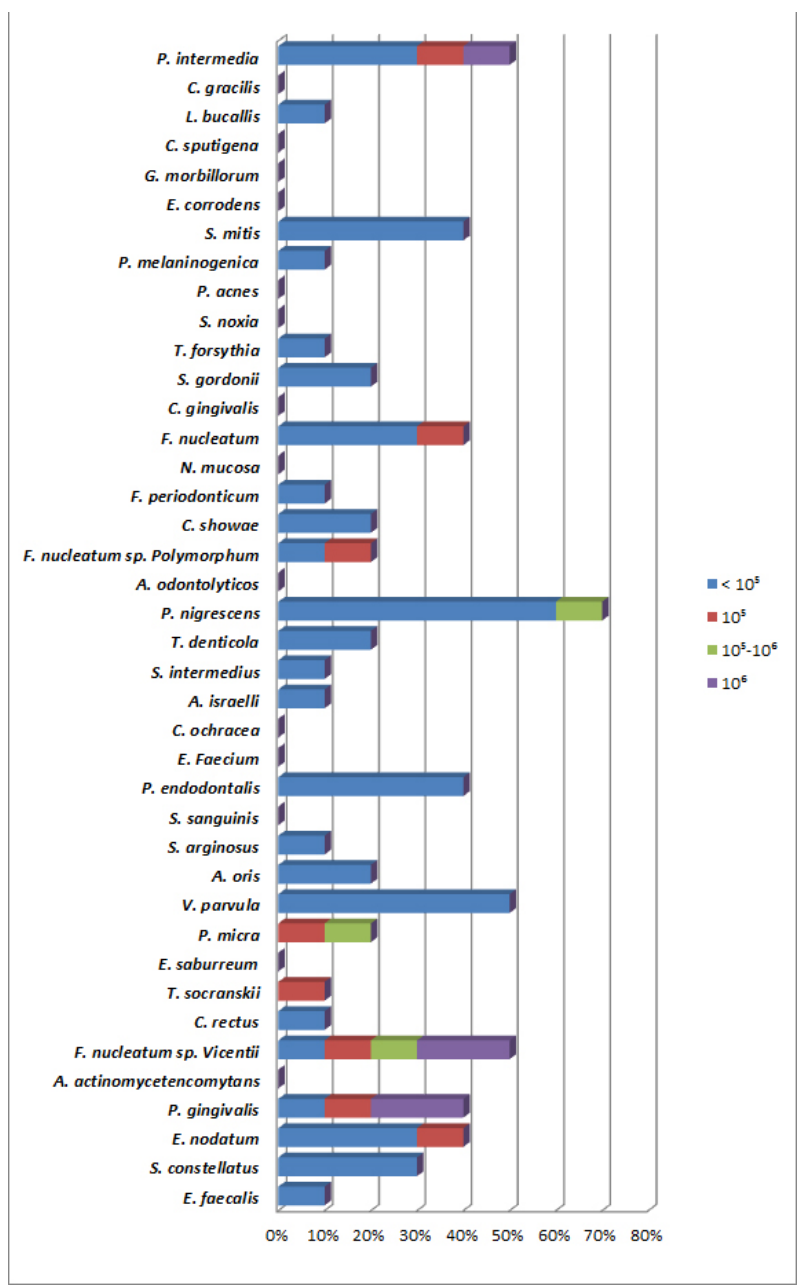

Figure 2. The mean prevalence (\% periodontal sample colonized) and levels $\left(<10^{5}, 10^{5}, 10^{5}-10^{6}\right.$ and $\left.10^{6}\right)$ of each bacterial species in samples of the periodontal pocket of endodontic-periodontal lesions. The total length of each bar indicates percentage of positive samples. Different colors inside each bar indicate percentage of samples containing different levels of bacterial DNA. 
LPS units were found in all samples, both periodontal and endodontic. The endotoxin levels $(\mathrm{EU} / \mathrm{mL})$ obtained in the periodontal pocket samples $(89600 \mathrm{EU} / \mathrm{mL})$ were significantly higher compared with the levels obtained in the root canal samples $(2310 \mathrm{EU} / \mathrm{mL})(p=0.002)$. Figure 3 shows the minimum, maximum and median values of endotoxins $(\mathrm{EU} / \mathrm{mL})$ found in the root canal and periodontal pocket.

\section{Discussion}

The effectiveness of the treatment of infectious diseases depends not only on the antimicrobial potential of the therapeutic strategies, but also on the susceptibility of the microbial species involved. The knowledge of the microbiological profile and endotoxin levels in endodontic-periodontal lesions can contribute to a better understanding of the pathogenesis of the disease, as well as to direct the therapeutic conducts. In addition, the use of antibiotics has been increasingly considered as an option to treat periodontal disease and the microbiological diagnosis may direct the choice of a specific antibiotic agent, also reducing the possibility of developing bacterial resistance (15). Thus, the main objective of this study was to investigate and identify the microbiological profile of $\vec{z}$ endodontic-periodontal lesions of periodontal origin by the checkerboard DNA-DNA hybridization method, as well as to quantify and correlate the endotoxin levels by the LAL assay. The checkerboard DNA-DNA hybridization is a rapid and sensitive molecular identification technique that permits the determination of the presence of multiple bacterial species in very large numbers of samples containing complex mixtures of microorganisms (16). Regarding its limitations, checkerboard technique can only detect species for which the DNA probes have been prepared, in addition to not detecting microorganisms that are below the detection limits of the method $\left(10^{3}\right.$ to $10^{4}$

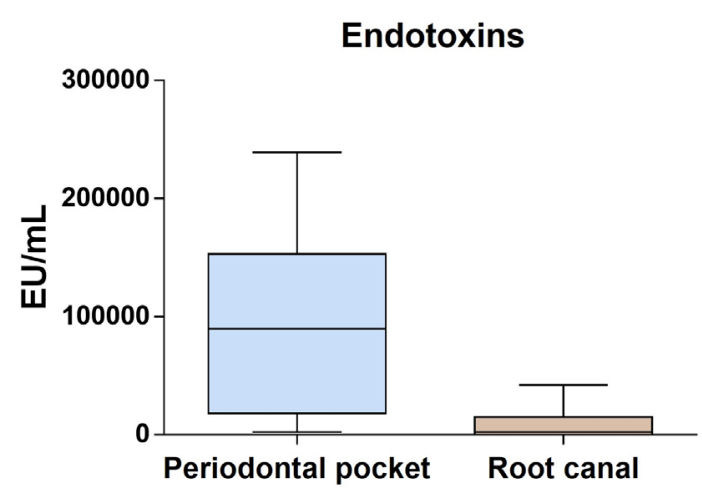

Figure 3. Median, maximum and minimum values of endotoxin levels $(\mathrm{EU} / \mathrm{mL})$ found in the root canal and periodontal pocket of endodontic-periodontal lesions. cells) (16). The method used for measuring the endotoxin levels has been previously published $(10,11)$ and has high sensitivity and precision (17). The 40 species investigated in this study were selected because of their association with endodontic/periodontal infections or their presence in other oral infections and saliva (18-21).

The microbiota of the root canal in endodonticperiodontal lesions was similar to that found in the periodontal pocket, suggesting a pathway of infection between the pulp and periodontal tissues, particularly through the apical foramen, accessory canals and/or dentinal tubules exposed to the buccal environment, corroborating previous studies $(2,4-8)$. Thus, the infected periodontal pocket was probably the main source of root canal infection in these cases of endoperiodontal lesions. The periodontal origin of the lesions was diagnosed because there was no evidence of pulpal aggression/infection via the dental crown, but rather a deep periodontal pocket and bone resorption progressing apically (13). The most prevalent species in the root canal samples were $P$. endodontalis (80\%), L. buccalis (80\%), C. sputigena (70\%), E. faecium (70\%), A. oris (70\%), V. parvula (70\%), P. micra (70\%), P. intermedia (60\%), G. morbillorum (60\%) and $E$. nodatum (60\%), all of them strict or facultative anaerobic bacteria. Other studies using culture-based methods also reported predominantly anaerobic polymicrobial flora in root canals of teeth with associated periodontal disease $(4,5)$. Higher prevalence of $P$. micra was also reported by Hong et al. (6) when studying the intracanal and periodontal bacterial community in teeth with combined endodonticperiodontal lesions, in addition to Porphyromonas gingivalis and Tannerella forsythia. The species E. faecium, P. acnes, G. morbillorum, C. sputigena and L. buccalis were strongly correlated with the endodontic microbiota in the present study, and were rarely detected in samples from the periodontal pocket, indicating that such bacteria are more specifically associated with endodontic microflora.

The most prevalent species in the periodontal samples were P. nigrescens (70\%), P. intermedia (50\%), V. parvula $(50 \%), F$. nucleatum $s s p$ vincentii $(50 \%), P$. gingivalis $(40 \%)$, P. endodontalis (40\%), F. nucleatum (40\%) and E. nodatum (40\%), all of them strict anaerobic bacteria. $P$. nigrescens was the only bacteria strongly correlated with the periodontal microbiota. Thus, there was a high prevalence of microorganisms of the orange complex in the periodontal pockets, known as the one with the greatest pathogenicity alongside the red complex (20). However, in addition to its relationship with periodontal pathogenicity, high incidence of this complex has also been associated with endodontic infections (22-24). Bacteria of the orange complex as, P. micra, P. intermedia and E. nodatum, were also prevalent in the root canal samples. Although they 
presented a weak association with both endodontic and periodontal microbiots, $P$. intermedia, P. endodontalis and $V$. parvula were predominant in both sites and may play a role in the pathogenesis of endoperiodontal lesions. Didilescu et al. (9) found a correlation of endodonticperiodontal infections with P. micra, F. nucleatum and C. sputigena, however in their study were analyzed cases with both primary and secondary endodontic infections. In the present investigation, these microorganisms were also found in both tissues, especially P. micra, but this correlation was not statistically significant.

Endodontic-periodontal lesions are characterized by a great bone loss $(3,8)$, what relate them to Gram-negative microorganisms and their endotoxins or LPS. In endodontics, LPS has been strongly correlated to pain and periapical bone resorption $(10,11)$. In the present study, the most prevalent bacteria in the periodontal pockets were Gramnegative bacteria, with the exception of E. nodatum. In the root canal samples, predominantly Gram-negative bacteria such as $P$. endodontalis, $L$. buccalis, $C$. sputigena, $V$. parvula and $P$. intermedia were also detected. The endotoxin level in the periodontal pocket $(89600 \mathrm{EU} / \mathrm{mL})$ was significantly higher in comparison with the root canal $(2310 \mathrm{EU} / \mathrm{mL})$ and this difference can be explained by the microbial load, specifically Gram-negative species, which was higher in the periodontium compared with the root canal, consistent with previous studies $(2,9)$. Duque et al. (25), through a clinical study, also found a higher level of LPS in the periodontal pockets than in the root canals in teeth with primary periodontal lesion and secondary endodontic involvement. The median value of $2310 \mathrm{EU} /$ $\mathrm{mL}$ obtained from root canals was high compared with other studies evaluating endotoxin levels in root canals with primary endodontic infections, whose levels ranged from 7.49-198 EU/mL $(10,11,17)$. This may be due to the methodological differences among works, mainly in relation to the sample collection method. Higher values obtained in this study can be explained by the fact that in our cases the periodontal pocket was already in communication with the apical foramen, which probably led to an increase in the number of microorganisms and LPS in root canals.

In conclusion, it was demonstrated that the microbiota present in the periodontal and endodontic tissues of teeth with endodontic-periodontal lesion is similar, with a higher prevalence of species of the orange complex, suggesting that the periodontal pocket may be an important source of root canal infection. The species E. faecium, P. acnes, G. morbillorum, $C$. sputigena and $L$. buccalis were strongly correlated with the endodontic microbiota and $P$. nigrescens with the periodontal microbiota. The species $P$. intermedia, $P$. endodontalis and $V$. parvula were predominant in both samples of the root canal and periodontal pocket and may play a role in the pathogenesis of endodontic-periodontal lesions. However, it is necessary to define the specific role played by these pathogens in this type of lesion and thus to determine the best therapeutic measures for its eradication. In addition, further studies evaluating all microorganisms by using DNA sequencing should be performed to evaluate other potential pathogens related to this type of lesion. The endotoxin levels found in the periodontal pocket was higher compared with the root canal.

\section{Resumo}

Este estudo foi realizado para investigar o perfil microbiano e os niveis de endotoxina de lesões endoperiodontais de origem periodontal. Amostras periodontais e endodônticas foram obtidas de bolsas periodontais e canais radiculares necróticos de 10 dentes com lesões endoperiodontais. A investigação de 40 espécies bacterianas diferentes foram determinadas em cada amostra endodôntica e periodontal usando o método de hibridização de DNA-DNA (checkerboard) e o ensaio cinético cromogênico LAL foi usado para quantificação de endotoxinas. 0 teste exato de Fisher correlacionou as espécies bacterianas com a microbiota endodôntica ou periodontal. Os niveis de endotoxina $(\mathrm{EU} / \mathrm{mL})$ encontrados nas amostras do canal radicular e na bolsa periodontal foram comparados pelo teste de Wilcoxon $(p<0,05)$. Bactérias e unidades de LPS foram encontradas em $100 \%$ das amostras endodônticas e periodontais. As espécies E. faecium, $P$. acnes, G. morbillorum, $C$. sputigena e $L$. buccalis foram fortemente correlacionadas com a microbiota endodôntica e $P$. nigrescens com a microbiota periodontal. $P$. intermedia, $P$. endodontalis e $V$. parvula foram mais prevalentes em ambas microbiotas endodôntica e periodontal. Os niveis de endotoxina na bolsa periodontal (89600 EU/ $\mathrm{mL}$ ) foram significativamente maiores do que no canal radicular (2310 $\mathrm{EU} / \mathrm{mL}$ ). Concluiu-se que a microbiota presente nos tecidos periodontal e endodôntico é semelhante, com maior prevalência de espécies do complexo laranja e maior nivel de endotoxina nas bolsas periodontais.

\section{References}

1. Jansson L, Ehnevid H, Lindskog S, Blomlöf L. Relationship between periapical and periodontal status. J Clin Periodontol 1993;20:117-123.

2. Rupf S, Kannengiesser S, Merte K, Pfister W, Sigusch B, Eschrich K. Comparison of profiles of key periodontal pathogens in periodontium and endodontium. Endod Dent Traumatol 2000;16:269-275.

3. Meng HX. Periodontic-endodontic lesions. Ann Periodontol 1999;4:8490.

4. Kipioti A, Nakou M, Legakis N, Mitsis F. Microbiological findings of infected root canals and adjacent periodontal pockets in teeth with advanced periodontitis. Oral Surgery, Oral Med Oral Pathol 1984;58:213-220.

5. Kobayashi T, Hayashi A, Yoshikawa R, Okuda K, Hara K. The microbial flora from root canals and periodontal pockets of non-vital teeth associated with advanced periodontitis. Int Endod J 1990;23:100-106.

6. Li H, Guan R, Sun J, Hou B. Bacteria community study of combined periodontal-endodontic lesions using denaturing gradient gel electrophoresis and sequencing analysis. J Periodontol 2014;85:14421449.

7. Gomes BPFA, Berber VB, Kokaras AS, Chen T, Paster BJ. Microbiomes of endodontic-periodontal lesions before and after chemomechanical preparation. J Endod 2015;41:1975-1984.

8. Solomon C, Chalfin H, Kellert M, Weseley P. The endodonticperiodontal lesion: a rational approach to treatment. J Am Dent Assoc 1995;126:473-479.

9. Didilescu AC, Rusu D, Anghel A, Nica L, Iliescu A, Greabu M, et al. Investigation of six selected bacterial species in endo-periodontal lesions. Int Endod J 2012;45:282-293.

10. Gomes BPFA, Endo MS, Martinho FC. Comparison of endotoxin levels found in primary and secondary endodontic infections. J Endod 
2012;38:1082-1086.

11. Cardoso FG, Ferreira NS, Martinho FC, Nascimento GG, Manhães LR, Rocco MA, et al. Correlation between volume of apical periodontitis determined by cone-beam computed tomography analysis and endotoxin levels found in primary root canal infection. J Endod 2015;41:1015-1019.

12. Fujihara $M$, Muroi $M$, Tanamoto $K I_{\text {, Suzuki }}$, Azuma $H$, Ikeda H. Molecular mechanisms of macrophage activation and deactivation by lipopolysaccharide: roles of the receptor complex. Pharmacol Ther 2003;100:171-194.

13. Simon JHS, Glick DH, Frank AL. The relationship of endodonticperiodontic lesions. J Endod 2013;39:e41-e46.

14. Feinberg AP, Vogelstein S. A technique for radio-labeling DNA fragments to high specific activity. Anal Biochem 1984;137:266-267.

15. Shaddox LM, Walker C. Microbial testing in periodontics: value, limitations and future directions. Periodontol 2000 2009;50:25-38.

16. Socransky SS, Haffajee AD, Smith C, Martin L, Haffajee JA, Uzel NG, et al. Use of checkerboard DNA-DNA hybridization to study complex microbial ecosystems. Oral Microbiol Immunol 2004;19:352-362.

17. Martinho FC, Chiesa WM, Zaia AA, Ferraz CC, Almeida JF, Souza-Filho FJ, et al. Comparison of endotoxin levels in previous studies on primary endodontic infections. J Endod 2011;37:163-167.

18. Gomes BP, Pinheiro ET, Gadê-Neto CR, Sousa EL, Ferraz CC, Zaia AA, et al. Microbiological examination of infected dental root canals. Oral Microbiol Immunol 2004;19:71-76.
19. Haffajee AD. Clinical and microbiological features of subjects with adult periodontitis who responded poorly to scaling and root planing. J Clin Periodontol 1997;24:767-776.

20. Socransky SS, Haffajee AD, Cugini MA, Smith C, Kent Jr. RL. Microbial complexes in subgingival plaque. J Clin Periodontol 1998;25:134-144.

21. Jung IY, Choi BK, Kum KY, Roh BD, Lee SJ, Lee CY, et al. Molecular epidemiology and association of putative pathogens in root canal infection. J Endod 2000;26:599-604.

22. Craig BJ, Falkler WA. Bacteria in the apical $5 \mathrm{~mm}$ of infected root canals. J Endod 1991;17:380-383.

23. Lana MA, Ribeiro-Sobrinho AP, Stehling R, Garcia GD, Silva BK, Hamdan $J S$, et al. Microorganisms isolated from root canals presenting necrotic pulp and their drug susceptibility in vitro. Oral Microbiol Immunol 2001;16:100-105.

24. Siqueira JF, Rôças IN, Alves FRF, Santos KRN. Selected endodontic pathogens in the apical third of infected root canals: a molecular investigation. J Endod 2004;30:638-643.

25. Duque TM, Prado M, Herrera DR, Gomes BPFA. Periodontal and endodontic infectious/inflammatory profile in primary periodontal lesions with secondary endodontic involvement after a calcium hydroxide-based intracanal medication. Clin Oral Investig 2018:1-11.

Received October 21, 2018 Accepted February 28, 2019 